\title{
PRACTICE PARAMETER: EVIDENCE-BASED GUIDELINES FOR MIGRAINE HEADACHE (AN EVIDENCE-BASED REVIEW)
}

\author{
Report of the Quality Standards Subcommittee of the American Academy of Neurology
}

Stephen D. Silberstein, MD, FACP, for the US Headache Consortium*

\begin{abstract}
Mission statement. The Quality Standards Subcommittee (QSS) of the American Academy of Neurology (AAN) is charged with developing practice parameters for physicians. This practice parameter summarizes the results from the four evidence-based reviews on the management of patients with migraine: specifically, acute, preventive, and nonpharmacologic treatments for migraine, and the role of neuroimaging in patients with headache. The full papers for these treatment guidelines are published elsewhere, ${ }^{1-6}$ and only the specific treatment recommendations are summarized below.
\end{abstract}

Background and justification. Migraine is a very common disorder. An estimated $18 \%$ of women and $6 \%$ of men experience migraine, but many go undiagnosed and undertreated. ${ }^{7}$ There have been a number of advances in the diagnosis and treatment of migraine as well as great strides in understanding its pathogenesis, making it one of the best understood of the neurologic disorders. Migraine is characterized by enhanced sensitivity of the nervous system. The attack is associated with activation of the trigeminal-vascular system.

In June 1998, Duke University's Center for Clinical Health Policy Research, in collaboration with the AAN, completed four Technical Reviews on migraine sponsored by the Agency for Health Care Policy and Research. These reviews covered self-administered drug treatments for acute migraine ${ }^{8}$; parenteral drug treatments for acute migraine ${ }^{9}$; drug treatments for the prevention of migraine ${ }^{10}$; and behavioral and physical treatments for migraine. ${ }^{11}$ The Education and Research Foundation of the AAN later funded additional reports on diagnostic testing for headache patients, an update on sumatriptan and other 5-HT 1 agonists, and a report on butalbital-containing compounds for migraine and tension-type headache, using the same methodology that was used in the original Technical Reviews. A multidisciplinary panel of professional organizations (The US Headache Consortium) produced four treatment guidelines, each related to a distinct set of management decisions: diagnostic testing (primarily neuroimaging studies), pharmacologic management of acute attacks, migraine-preventive drugs, and behavioral and physical treatments for migraine.

Clinical question statements. Specific clinical questions addressed in these practice parameters included the following: Acute and preventive treatment- What are the effects on acute headache pain of medications taken during the attack? What are the effects on the frequency and/or severity of migraine attacks of medications taken on a daily basis for prevention of migraine? How safe and tolerable are acute and preventive migraine medications? How do the efficacy and tolerability issues of medications for migraine compare to placebo, alternative medications, and nonpharmacologic techniques?

Diagnostic testing - What is the role of neuroimaging in patients who present with headache? Are particular findings in the history and on the physical examination helpful in identifying which patients have significant intracranial abnormalities? What is the frequency of significant secondary causes of nonacute headache, as detected by CT or MRI, in patients who present with nonacute headache and a normal neurologic examination? What evidence exists concerning the relative ability of CT and MRI to detect significant intracranial lesions among patients with nonacute headache?

Description of the process. Seven organizations participated in The US Headache Consortium: the American Academy of Family Physicians, AAN, American Headache Society (formerly the American Association for the Study of

\footnotetext{
${ }^{*}$ Members of the US Headache Consortium are listed in Appendix 1.

From the American Academy of Neurology, St. Paul, MN.

Approved by the Quality Standards Subcommittee April 1, 2000. Approved by the Practice Committee May 3, 2000. Approved by the AAN Board of Directors June 9, 2000

The Evidence-Based Guidelines for Migraine Headache were supported by: Abbott Laboratories, Astra Zeneca, Bristol Myers Squibb, Glaxo Wellcome, Merck, Pfizer, Ortho-McNeil, and the AAN Education \& Research Foundation, along with the seven participant member organizations. Received April 6, 2000. Accepted in final form August 9, 2000.

Address correspondence and reprint requests to Wendy Edlund, American Academy of Neurology, 1080 Montreal Avenue, St. Paul, MN 55116; phone: 651-695-1940.
} 
Headache), American College of Emergency Physicians, American College of Physicians-American Society of Internal Medicine, American Osteopathic Association, and National Headache Foundation. Complete descriptions of the methodologic details are described elsewhere. ${ }^{2}$

Analysis of evidence. Evidence supporting the acute treatment and preventive treatment were exclusively Class I studies; however, due to the lack of published Class I evidence, Class II and Class III studies were included for analysis of diagnostic testing and utility of neuroimaging in migraine. Clearly effective migraine treatments and techniques are available for the acute and preventive treatment of migraine. However, there are few studies on the relative efficacy of these agents or how to implement these treatments into successful treatment strategies.

Diagnosis of migraine. The 1988 International Headache Society (IHS) classification of headache system is almost universally accepted and has become the basis for headache classification in the International Classification of Diseases (ICD-10b). ${ }^{12}$ Migraine is a chronic condition with recurrent episodic attacks. Its characteristics vary among patients and often among attacks in a single patient. To diagnose migraine, it is necessary to exclude secondary headache causes and then determine whether the patient has any other coexisting primary headache (e.g., tension-type headache). Testing is not recommended if the individual is not significantly more likely than anyone else in the general population to have a significant abnormality. Testing should be avoided if it will not lead to a change in management. However, testing that normally may not be recommended as a population policy may make sense at an individual level. Exceptions can be considered for patients who are disabled by their fear of serious pathology or for patients about whom the provider is suspicious even in the absence of known predictors of abnormalities on neuroimaging studies (red flags). (In the acute headache setting, which was outside of the original guidelines, risk factors for intracranial pathology include acute onset, occipitonuchal location, age $>55$ years, associated symptoms, and an abnormal neurologic examination. Headache type, severity, characteristics, or duration were not risk factors. ${ }^{13}$ )

There was insufficient published clinical research to support evidence-based guidelines for any diagnostic testing other than neuroimaging. Previous reports that reviewed the evidence on the role of EEG found that it is not indicated in the routine evaluation of headache. ${ }^{14}$

The following symptoms significantly increased the odds of finding a significant abnormality on neuroimaging in patients with nonacute headache:

- Rapidly increasing headache frequency

- History of lack of coordination

- History of localized neurologic signs or a history such as subjective numbness or tingling

- History of headache causing awakening from sleep (although this can occur with migraine and cluster headache)

The absence of these symptoms did not significantly lower the odds of finding a significant abnormality on neuroimaging.

Neuroimaging recommendations for nonacute headache are as follows:

- Consider neuroimaging in:

Patients with an unexplained abnormal finding on the neurologic examination (Grade B)

Patients with atypical headache features or headaches that do not fulfill the strict definition of migraine or other primary headache disorder (or have some additional risk factor, such as immune deficiency), when a lower threshold for neuroimaging may be applied (Grade C)

- Neuroimaging is not usually warranted in patients with migraine and a normal neurologic examination (Grade B).

- No evidence-based recommendations are established for the following:

Presence or absence of neurologic symptoms (Grade C)

Tension-type headache (Grade C)

Relative sensitivity of MRI as compared with CT in the evaluation of migraine or other nonacute headache (Grade C)

Treatment of migraine. Migraine varies in frequency, duration, and disability among sufferers and between attacks. It is appropriate to link the intensity of care with the level of disability and symptoms such as nausea and vomiting (stratified care) for the acute treatment of symptoms of an ongoing attack. It is not appropriate to continue ineffective or poorly tolerated medication in a sequential and arbitrary manner (step care). Consider preventive treatment (given on an ongoing basis whether or not an attack is present) for those patients whose migraine has a substantial impact on their lives and have not responded to acute care, or where the frequency of migraine attacks is such that the reliance on acute care medications would increase the potential for drug-induced (rebound) headache. The goals of long-term migraine treatment, both pharmacologic and nonpharmacologic, are to: 
- Reduce attack frequency, severity, and disability

- Reduce reliance on poorly tolerated, ineffective, or unwanted acute pharmacotherapies

- Improve quality of life

- Avoid acute headache medication escalation

- Educate and enable patients to manage their disease to enhance personal control of their migraine

- Reduce headache-related distress and psychological symptoms

Behavioral and physical interventions are used for preventing migraine episodes rather than for alleviating symptoms once an attack has begun. Although these modalities may be effective as monotherapy, they are more commonly used in conjunction with pharmacologic management.

\section{General principles of management.}

- Establish a diagnosis.

- Educate migraine sufferers about their condition and its treatment. Discuss the rationale for a particular treatment, how to use it, and what adverse events are likely.

- Establish realistic patient expectations by setting appropriate goals and discussing the expected benefits of therapy and how long it will take to achieve them. Empower the patients to be actively involved in their own management by encouraging patients to track their own progress through the use of diary cards, flow charts, headache calendars, and forms for tracking days of disability or missed work, school, or family activities. Treatment choice depends on the frequency and severity of attacks, the presence and degree of temporary disability, and associated symptoms such as nausea and vomiting.

- Create a formal management plan and individualize management: consider the patient's response to, and tolerance for, specific medications. Consider comorbidity/coexisting conditions. Coexisting conditions (such as heart disease, pregnancy, and uncontrolled hypertension) need to be ascertained as they may limit treatment choices.

- Encourage the patient to identify and avoid triggers.

Acute treatment. Goals of acute migraine treatment are as follows:

1. Treat attacks rapidly and consistently without recurrence.

2. Restore the patient's ability to function.

3. Minimize the use of back-up and rescue medications. (A rescue medication is used at home when other treatments fail and permits the patient to achieve relief without the discomfort and expense of a visit to the physician's office or emergency department.)

4. Optimize self-care and reduce subsequent use of resources.

5. Be cost-effective for overall management.

6. Have minimal or no adverse events.

To meet these goals:

- Use migraine-specific agents (triptans, dihydroergotamine [DHE]) in patients with moderate or severe migraine or whose mild-to-moderate headaches respond poorly to nonsteroidal anti-inflammatory drugs (NSAIDs) or combinations such as aspirin plus acetaminophen plus caffeine. Failure to use an effective treatment promptly may increase pain, disability, and the impact of the headache.

- Select a nonoral route of administration for patients with migraine associated with severe nausea or vomiting. Antiemetics should not be restricted to patients who are vomiting or likely to vomit. Nausea itself is one of the most aversive and disabling symptoms of a migraine attack and should be treated appropriately.

- Consider a self-administered rescue medication for patients with severe migraine who do not respond to (or fail) other treatments.

- Guard against medication-overuse headache ("rebound headache" or "drug-induced headache"). Frequent use of acute medications (ergotamine [not DHE], opiates, triptans, simple analgesics, and mixed analgesics containing butalbital, caffeine, or isometheptene) is generally thought to cause medication-overuse headache. Many experts limit acute therapy to two headache days per week on a regular basis. Patients with medication overuse should use preventive therapy.

Evidence-based recommendations for acute treatment of migraine. A summary of evidence for treatment of acute attacks of migraine is presented in table 1 . Table 2 provides a summary of acute therapies for migraine.

Specific medications.

Triptans (serotonin 1 IB/ID receptor agonists). 
- Naratriptan, rizatriptan, sumatriptan, and zolmitriptan. Triptans are effective and relatively safe for the acute treatment of migraine headaches and are an appropriate initial treatment choice in patients with moderate to severe migraine who have no contraindications for its use (Grade A).

- Initial treatment with any triptan is a reasonable choice when the headache is moderate to severe or in migraine of any severity when nonspecific medication has failed to provide adequate relief in the past (Grade C).

- $\quad$ Patients with nausea and vomiting may be given intranasal or subcutaneous sumatriptan (Grade C).

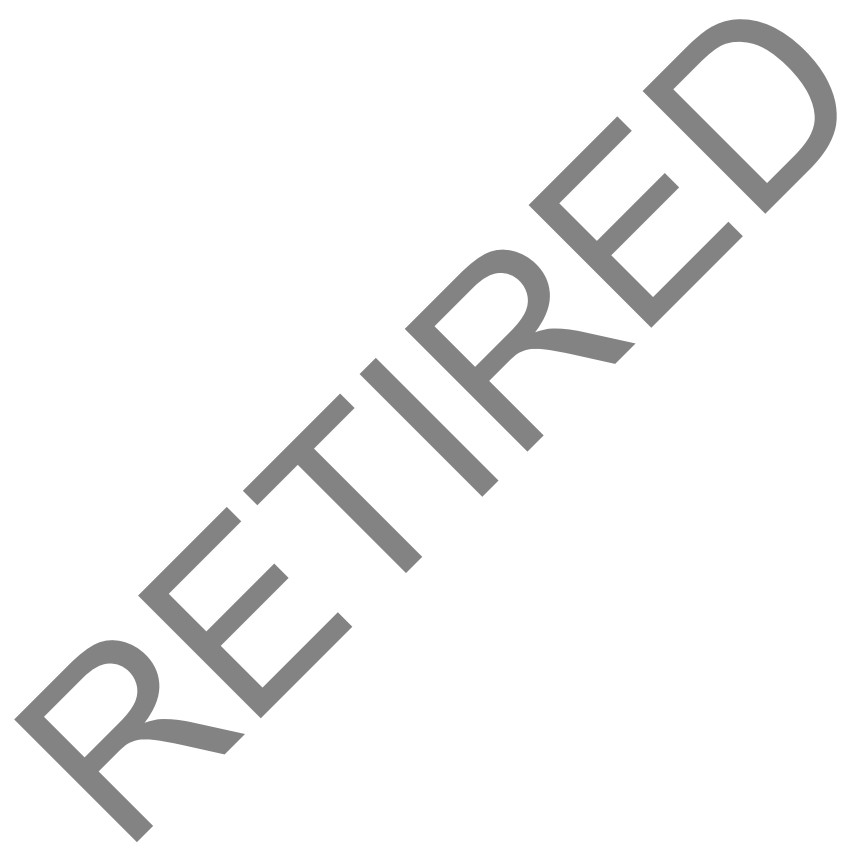


Table 1 Evidence summary for treatment of acute attacks of migraine

\begin{tabular}{|c|c|c|c|c|c|}
\hline Drug & $\begin{array}{l}\text { Quality of } \\
\text { evidence* }\end{array}$ & $\begin{array}{l}\text { Scientific } \\
\text { effect* }\end{array}$ & $\begin{array}{l}\text { Clinical } \\
\text { impression of } \\
\text { effect* }\end{array}$ & $\begin{array}{l}\text { Adverse } \\
\text { effects }\end{array}$ & Role (by consensus) \\
\hline \multicolumn{6}{|l|}{$\begin{array}{l}\text { Triptans (serotonin }{ }_{1 \mathrm{~B} / 1 \mathrm{D}} \text { receptor } \\
\text { agonists) }\end{array}$} \\
\hline Sumatriptan nasal spray & A & +++ & +++ & Occasional & $\begin{array}{l}\text { Moderate-to-severe migraine. Useful when } \\
\text { nonoral route needed. Less severe migraine } \\
\text { when nonopiate medications fail. }\end{array}$ \\
\hline Oral triptans & & & & & $\begin{array}{l}\text { Moderate-to-severe migraine. Less severe } \\
\text { migraine when nonopiate medications fail. }\end{array}$ \\
\hline Naratriptan & A & ++ & ++ & Infrequent & \\
\hline Rizatriptan & A & +++ & +++ & Occasional & \\
\hline Sumatriptan & A & +++ & +++ & Occasional & \\
\hline Zolmitriptan & A & +++ & +++ & Occasional & \\
\hline Sumatriptan SC & A & +++ & +++ & Frequent & $\begin{array}{l}\text { Moderate-to-severe migraine. Useful when } \\
\text { nonoral route needed. Less severe migraine } \\
\text { when nonopiate medications fail. }\end{array}$ \\
\hline \multicolumn{6}{|l|}{ Ergot alkaloids and derivatives } \\
\hline DHE IV plus antiemetics & $\mathrm{B}$ & +++ & +++ & Frequent & $\begin{array}{l}\text { Status migrainosus. Therapy of choice in } \\
\text { emergency department. }\end{array}$ \\
\hline DHE nasal spray & $\mathrm{A}$ & ++ & ++ & & $\begin{array}{l}\text { Moderate-to-severe migraine. Less severe } \\
\text { migraine when nonopiate medications fail. } \\
\text { Low recurrence. } \\
\text { Consider for selected patients with moderate-to- } \\
\text { severe migraine. }\end{array}$ \\
\hline \multicolumn{6}{|l|}{$\begin{array}{l}\text { Ergotamine plus caffeine } \\
\text { Antiemetics }\end{array}$} \\
\hline $\begin{array}{l}\text { Chlorpromazine IM/IV } \\
\text { Metoclopramide IM }\end{array}$ & $\mathrm{C} / \mathrm{B}$ & ++ & & & $\begin{array}{l}\text { Adjunct therapy. May be choice for acute } \\
\text { therapy. } \\
\text { Adjunct therapy. May be choice for acute } \\
\text { therapy. }\end{array}$ \\
\hline $\mathrm{PR} / \mathrm{IV}$ & $\mathrm{B}$ & 1 & & & \\
\hline Prochlorperazine PR/IM & $\mathrm{B}$ & & & Occasional & $\begin{array}{l}\text { IM/IV adjunct first-line therapy in emergency } \\
\text { department or office; consider PR as adjunct. }\end{array}$ \\
\hline Acetaminophen & $\mathrm{B}$ & 0 & + & Infrequent & Pregnant migraineur. \\
\hline Ketorolac IM & $\mathrm{B}$ & & ++ & Infrequent & Consider in emergency department. \\
\hline Oral NSAIDS & & & & Occasional & First-line for mild-to-moderate migraine. \\
\hline Aspirin & A & & ++ & & \\
\hline Diclofenac K & $\mathrm{B}$ & & ++ & & \\
\hline Flurbiprofen & & & ++ & & \\
\hline Ibuprofen & & & ++ & & \\
\hline Naproxen & & + & ++ & & \\
\hline Naproxen sodium & & ++ & ++ & & \\
\hline \multicolumn{6}{|l|}{ Combination analgesics } \\
\hline \multicolumn{6}{|l|}{ Barbiturate hypnotics } \\
\hline Butalbital, ASA, caffeine & $\mathrm{C}$ & $?$ & +++ & Occasional & $\begin{array}{l}\text { Occasional use for moderate-to-severe migraine. } \\
\text { Limit use due to risk of overuse. }\end{array}$ \\
\hline Butalbital, ASA, caffeine, codeine & $\mathrm{B}$ & ++ & +++ & & \\
\hline \multicolumn{6}{|l|}{ Opiate analgesics } \\
\hline Butorphanol nasal spray & A & +++ & +++ & Frequent & $\begin{array}{l}\text { Moderate to severe migraine; rescue therapy. } \\
\text { Limit use. }\end{array}$ \\
\hline Opiates —oral combinations & A & ++ & ++ & Occasional & $\begin{array}{l}\text { Moderate to severe migraine; rescue therapy. } \\
\text { Limit use. }\end{array}$ \\
\hline \multicolumn{6}{|l|}{$\begin{array}{l}\text { Acetaminophen, codeine } \\
\text { combinations }\end{array}$} \\
\hline Opiates_-parenteral & $\mathrm{B}$ & ++ & ++ & Frequent & $\begin{array}{l}\text { Reserved for emergency department use or } \\
\text { rescue medication. } \\
\text { Limit use. }\end{array}$ \\
\hline \multicolumn{6}{|l|}{ Butorphanol IM } \\
\hline \multicolumn{6}{|l|}{ Meperidine IM/IV } \\
\hline \multicolumn{6}{|l|}{ Other medications } \\
\hline $\begin{array}{l}\text { Corticosteroids } \\
\text { IV plus antiemetics } \\
\text { Dexamethasone } \\
\text { Hydrocortisone }\end{array}$ & $\mathrm{C}$ & + & ++ & Infrequent & Rescue therapy in status migrainosus. \\
\hline Isometheptene compound & $\mathrm{B}$ & + & ++ & Infrequent & Mild-to-moderate headache. \\
\hline
\end{tabular}


Table 2 Acute therapies for migraine

\begin{tabular}{|c|c|c|c|c|}
\hline \multirow{2}{*}{$\begin{array}{l}\text { Group 1* } \\
\text { Specific }\end{array}$} & Group $2 \dagger$ & Group 3t & Group $4 \S$ & Group 5 \\
\hline & Acetaminophen plus codeine PO & $\begin{array}{l}\text { Butalbital, aspirin, plus } \\
\text { caffeine PO }\end{array}$ & Acetaminophen PO & Dexamethasone IV \\
\hline Naratriptan PO & $\begin{array}{l}\text { Butalbital, aspirin, caffeine, plus } \\
\text { codeine PO }\end{array}$ & Ergotamine PO & Chlorpromazine IM & Hydrocortisone IV \\
\hline Rizatriptan PO & Butorphanol IM & Ergotamine plus caffeine PO & Granisetron IV & \\
\hline Sumatriptan SC, IN, PO & Chlorpromazine IM, IV & Metoclopramide IM, PR & Lidocaine IV & \\
\hline Zolmitriptan $\mathrm{PO}$ & Diclofenac K, PO & & & \\
\hline DHE SC, IM, IV, IN & $\begin{array}{l}\text { Ergotamine plus caffeine plus } \\
\text { pentobarbital plus } \\
\text { Bellafoline }{ }^{\mathbb{B}} \text { PO }\end{array}$ & & & \\
\hline DHE IV, plus antiemetic & Flurbiprofen, PO & & & \\
\hline Nonspecific & Isometheptene CPD, PO & & & \\
\hline $\begin{array}{l}\text { Acetaminophen, aspirin, } \\
\text { plus caffeine PO }\end{array}$ & Ketorolac IM & & & \\
\hline Aspirin PO & Lidocaine IN & & & \\
\hline Butorphanol IN & Meperidine IM, IV & & & \\
\hline Ibuprofen PO & Methadone IM & & & \\
\hline Naproxen sodium PO & Metoclopramide IV & & & \\
\hline \multirow[t]{2}{*}{ Prochlorperazine IV } & Naproxen PO & & & \\
\hline & Prochlorperazine IM, PR & & & \\
\hline \multirow{2}{*}{\multicolumn{5}{|c|}{$\begin{array}{l}\text { * Proven, pronounced statistical and clinical benefit (at least two double-blind, placebo-controlled studies and clinical impression of effect). } \\
\end{array}$}} \\
\hline & & & & \\
\hline \multicolumn{5}{|c|}{ \$ Statistically but not proven clinically or clinically but not proven statistically effective (conflicting or inconsistent evidence). } \\
\hline inical and statistical be & inknown (insufficient evidenc & able). & & \\
\hline
\end{tabular}

- $\quad$ Ergotamine PO/PR (and caffeine combination) may be considered in the treatment of selected patients with moderate to severe migraine (Grade B).

- $\quad$ DHE nasal spray is safe and effective for the treatment of acute migraine attacks and should be considered for use in patients with moderate to severe migraine (Grade A).

- $\quad$ DHE SC/IV/IM and nasal spray may be given to patients with nausea and vomiting (Grade C).

- $\quad$ DHE SC, IM, and nasal spray are reasonable initial treatment choices when the headache is moderate to severe, or in migraine of any severity when nonspecific medication has failed to provide adequate relief in the past (Grade $\mathrm{C}$ ).

- $\quad$ DHE IM, SC may be considered in patients with moderate to severe migraine (Grade B).

- $\quad$ DHE IV plus antiemetics IV is an appropriate treatment choice for patients with severe migraine (Grade B).

Nonspecific medications.

Antiemetics.

- Oral antiemetics are an adjunct to treat nausea associated with migraine (Grade C).

- Metoclopramide IM/IV is an adjunct to control nausea (Grade C) and may be considered as IV monotherapy for migraine pain relief (Grade B).

- Prochlorperazine IV, IM, and PR may be a therapeutic choice for migraine in the appropriate setting (Grade B).

- Prochlorperazine PR is an adjunct in the treatment of acute migraine with nausea and vomiting (Grade C).

- Chlorpromazine IV may be a therapeutic choice for migraine in the appropriate setting (Grade B).

- Serotonin receptor (5- $\left.\mathrm{HT}_{3}\right)$ antagonists are not effective as monotherapy for migraine pain relief (Grade B), but may be considered as adjunct therapy to control nausea in selected patients with migraine attacks (Grade C).

NSAIDs, nonopiate analgesics, and combination analgesics.

- Acetaminophen, alone, is not recommended for migraine (Grade B).

- NSAIDs (oral) and combination analgesics containing caffeine are a reasonable first-line treatment choice for mild to moderate migraine attacks or severe attacks that have been responsive in the past to similar NSAIDs or nonopiate analgesics (Grade A). Ketorolac IM is an option that may be used in a physician-supervised setting, although conclusions regarding clinical efficacy cannot be made at this time (Grade C).

Butalbital-containing analgesics.

- Limit and carefully monitor their use based on overuse, medication-overuse headache, and withdrawal concerns (Grade B).

Opiate analgesics. 
Table 3 Preventive therapies for migraine

\begin{tabular}{|c|c|c|c|c|c|}
\hline Therapies & $\begin{array}{l}\text { Quality of } \\
\text { evidence* }\end{array}$ & $\begin{array}{c}\text { Scientific } \\
\text { effect* }\end{array}$ & $\begin{array}{c}\text { Clinical } \\
\text { impression } \\
\text { of effect* }\end{array}$ & Adverse effects & Group $^{\dagger}$ \\
\hline \multicolumn{6}{|l|}{ Antiepileptics } \\
\hline Carbamazepine & B & ++ & 0 & Occasional to frequent & 5 \\
\hline Divalproex sodium/sodium valproate & A & +++ & +++ & Occasional to frequent & 1 \\
\hline Gabapentin & B & ++ & ++ & Occasional to frequent & 2 \\
\hline Topiramate & $\mathrm{C}$ & $?$ & ++ & Occasional to frequent & $3 \mathrm{a}$ \\
\hline \multicolumn{6}{|l|}{ Antidepressants } \\
\hline \multicolumn{6}{|l|}{ Tricyclic antidepressants } \\
\hline Amitriptyline & A & +++ & +++ & Frequent & 1 \\
\hline Nortriptyline & $\mathrm{C}$ & $?$ & +++ & Frequent & $3 a$ \\
\hline Protriptyline & $\mathrm{C}$ & $?$ & ++ & Frequent & $3 a$ \\
\hline Doxepin, imipramine & $\mathrm{C}$ & ? & + & Frequent & $3 \mathrm{a}$ \\
\hline \multicolumn{6}{|l|}{ Selective serotonin reuptake inhibitors } \\
\hline Fluoxetine & B & + & + & Occasional & 2 \\
\hline Fluvoxamine, paroxetine, sertraline & $\mathrm{C}$ & ? & + & Occasional & $3 \mathrm{a}$ \\
\hline \multicolumn{6}{|l|}{ Monoamine oxidase inhibitors } \\
\hline Phenelzine & $\mathrm{C}$ & $?$ & +++ & Frequent & $3 b$ \\
\hline \multicolumn{6}{|l|}{ Other antidepressants } \\
\hline Bupropion, mirtazepine, trazodone, venlafaxine & $\mathrm{C}$ & $?$ & + & Occasional & $3 a$ \\
\hline \multicolumn{6}{|l|}{ Beta-blockers } \\
\hline Atenolol & B & ++ & T & Infrequent to occasional & 2 \\
\hline Metoprolol & B & ++ & & Infrequent to occasional & 2 \\
\hline Nadolol & B & + & +++ & Infrequent to occasional & 2 \\
\hline Propranolol & A & & +++ & Infrequent to occasional & 1 \\
\hline Timolol & A & & & Infrequent to occasional & 1 \\
\hline \multicolumn{6}{|l|}{ Calcium channel blockers } \\
\hline Diltiazem & $\mathrm{C}$ & & 0 & Infrequent to occasional & $3 a$ \\
\hline Nimodipine & B & & ++ & Infrequent to occasional & 2 \\
\hline Verapamil & B & & ++ & Infrequent to occasional & 2 \\
\hline \multicolumn{6}{|l|}{ NSAIDs } \\
\hline Aspirin & & & + & Infrequent & 2 \\
\hline \multicolumn{6}{|l|}{ Fenoprofen } \\
\hline \multicolumn{6}{|l|}{ Flurbiprofen } \\
\hline \multicolumn{6}{|l|}{ Mefenamic acid } \\
\hline Ibuprofen & & ? & + & Infrequent & $3 \mathrm{a}$ \\
\hline Ketoprofen & & + & + & Infrequent & 2 \\
\hline Naproxen/naproxen sodium & & + & + & Infrequent & 2 \\
\hline \multicolumn{6}{|l|}{ Serotonin antagonists } \\
\hline Cyproheptadine & $\mathrm{C}$ & $?$ & + & Frequent & $3 a$ \\
\hline Methysergide & A & +++ & +++ & Frequent & 4 \\
\hline \multicolumn{6}{|l|}{ Other } \\
\hline Feverfew & B & ++ & + & Infrequent & 2 \\
\hline Magnesium & B & + & + & Infrequent & 2 \\
\hline Vitamin B2 & B & +++ & ++ & Infrequent & 2 \\
\hline
\end{tabular}

* See Appendix 2 for explanations of quality of evidence, scientific effect, and clinical impression of effect.

${ }^{\dagger}$ Scale 1-5; see text for definitions.

$?=$ not known; NSAIDs $=$ nonsteroidal anti-inflammatory drugs

- Butorphanol nasal spray is a treatment option for some patients with migraine (Grade A). Butorphanol may be considered when other medications cannot be used or as a rescue medication when significant sedation would not jeopardize the patient (Grade C). Butorphanol is widely used despite the established risk of overuse and dependence. Special attention should be given to these clinical concerns.

- $\quad$ Parenteral opiates are a rescue therapy for acute migraine when sedation side effects will not put the patient at risk and when the risk abuse has been addressed (Grade B).

- Consider parenteral and oral combination use in acute migraine only when the risk of abuse has been addressed and sedation will not put the patient at risk (Grade A).

Other medications.

- Isometheptene and isometheptene combination agents may be a reasonable choice for patients with mild-to-moderate headache (Grade B).

- Corticosteroids (dexamethasone or hydrocortisone) are a treatment choice for rescue therapy for patients with status migrainosus (Grade C).

- Evidence is insufficient at this time to establish a defined role for intranasal lidocaine or lidocaine IV in the management of acute migraine headache (Grade B). 
Table 4 Preventive therapies for migraine*

\begin{tabular}{|c|c|c|c|c|}
\hline Group $1 \dagger$ & Group 2\$ & Group $3 \S$ & Group 4 & Group 5\| \\
\hline $\begin{array}{l}\text { Amitriptyline } \\
\text { Divalproex sodium } \\
\text { Propranolol/timolol }\end{array}$ & $\begin{array}{l}\text { B-blockers } \\
\text { Atenolol/metoprolol/nadolol } \\
\text { Ca-blockers } \\
\text { Nimodipine/verapamil } \\
\text { NSAIDs } \\
\text { Aspirin/fenoprofen/flurbiprofen } \\
\text { Ketoprofen } \\
\text { Mefenamic acid } \\
\text { Naproxen } \\
\text { Naproxen sodium } \\
\text { Fluoxetine (racemic) } \\
\text { Gabapentin } \\
\text { Other } \\
\text { Feverfew } \\
\text { Magnesium } \\
\text { Vitamin B2 }\end{array}$ & $\begin{array}{l}\text { A: Antidepressants } \\
\text { Bupropion } \\
\text { Doxepine } \\
\text { Fluvoxamine } \\
\text { Imipramine } \\
\text { Mirtazepine } \\
\text { Nortriptyline } \\
\text { Paroxetine } \\
\text { Protriptyline } \\
\text { Sertraline } \\
\text { Trazodone } \\
\text { Venlafaxine } \\
\text { Other } \\
\text { Cyproheptadine } \\
\text { Diltiazem } \\
\text { Ibuprofen } \\
\text { Topiramate } \\
\text { B: (side effect concerns) } \\
\text { Phenelzine }\end{array}$ & Methysergide & $\begin{array}{l}\text { Carbamazepine } \\
\text { Clomipramine } \\
\text { Clonazepam } \\
\text { Clonidine } \\
\text { Indomethacin } \\
\text { Nicardipine } \\
\text { Nifedipine } \\
\text { Pindolol }\end{array}$ \\
\hline
\end{tabular}

* Does not include combination products

$\dagger$ Medium to high efficacy, good strength of evidence, and mild-to-moderate side effects.

\$ Lower efficacy than those listed in first column, or limited strength of evidence, and mild-to-moderate side effects.

$\S$ Clinically efficacious based on consensus and clinical experience, but no scientific evidence of efficacy

I Medium to high efficacy, good strength of evidence, but with side effect concerns.

|| Evidence indicating no efficacy over placebo.

Preventive treatment. Tables 3 and 4 summarize preventive therapies for migraine. The goals of migraine preventive therapy are to: 1) reduce attack frequency, severity, and duration; 2) improve responsiveness to treatment of acute attacks; and 3) improve function and reduce disability. One or more of the following helps guide management decisions on the use of preventive therapies:

- Recurring migraines that, in the patients' opinion, significantly interfere with their daily routines, despite acute treatment

- Frequent headaches

- Contraindication to or failure or overuse of acute therapies

- Adverse events with acute therapies

- The cost of both acute and preventive therapies

- Patient preference

- Presence of uncommon migraine conditions, including hemiplegic migraine, basilar migraine, migraine with prolonged aura, or migrainous infarction (to prevent neurologic damage - as based on expert consensus)

These consensus-based principles of care will enhance the success of preventive treatment. Consider nonpharmacologic therapies and take patient preference into consideration.

1. Medication use:

A. Initiate therapy with medications that have the highest level of evidence-based efficacy.

B. Initiate therapy with the lowest effective dose of the drug. Increase it slowly until clinical benefits are achieved in the absence of, or until limited by, adverse events.

C. Give each drug an adequate trial. It may take 2 to 3 months to achieve clinical benefit.

D. Avoid interfering medications (e.g., overuse of acute medications).

E. Use of a long-acting formulation may improve compliance.

2. Evaluation:

A. Monitor the patient's headache through a headache diary.

B. Re-evaluate therapy. If after 3 to 6 months headaches are well controlled, consider tapering or discontinuing treatment.

3. Take coexisting conditions into account. Some (comorbid/coexisting) conditions are more common in persons with migraine: stroke, myocardial infarction, Raynaud's phenomenon, epilepsy, affective and anxiety disorders. These conditions present both treatment opportunities and limitations:

A. Select a drug that will treat the coexistent condition and migraine, if possible.

B. Establish that the treatments being used for migraine are not contraindicated for the coexistent disease.

C. Establish that the treatments being used for coexistent conditions do not exacerbate migraine.

D. Beware of all drug interactions. 
4. Direct special attention to women who are pregnant or want to become pregnant. Preventive medications may have teratogenic effects. If treatment is absolutely necessary, select a treatment with the lowest risk of adverse effects to the fetus.

5. Many migraine patients try nonpharmacologic treatment to manage their headaches before they begin drug therapy or concurrently with drug therapy. Behavioral treatments are classified into three broad categories: relaxation training, biofeedback therapy, and cognitive-behavioral training (stress-management training). Physical treatment includes acupuncture, cervical manipulation, and mobilization therapy. These are treatment options for headache sufferers who have one or more of the following characteristics:

A. Patient preference for nonpharmacologic interventions

B. Poor tolerance to specific pharmacologic treatments

C. Medical contraindications for specific pharmacologic treatments

D. Insufficient or no response to pharmacologic treatment

E. Pregnancy, planned pregnancy, or nursing

F. History of long-term, frequent, or excessive use of analgesic or acute medications that can aggravate headache problems (or lead to decreased responsiveness to other pharmacotherapies)

G. Significant stress or deficient stress-coping skills

Cognitive and behavioral treatment recommendations.

- Relaxation training, thermal biofeedback combined with relaxation training, electromyographic biofeedback, and cognitive-behavioral therapy may be considered as treatment options for prevention of migraine (Grade A). Specific recommendations regarding which of these to use for specific patients cannot be made.

- Behavioral therapy may be combined with preventive drug therapy to achieve additional clinical improvement for migraine relief (Grade B).

- Evidence-based treatment recommendations regarding the use of hypnosis, acupuncture, transcutaneous electrical nerve stimulation, chiropractic or osteopathic cervical manipulation, occlusal adjustment, and hyperbaric oxygen as preventive or acute therapy for migraine are not yet possible.

Pharmacologic preventive therapy.

Individual medications have been put into treatment groups based on their established clinical efficacy, significant adverse events, safety profile, and clinical experience of the US Headache Consortium participants:

Group 1. Medications with proven high efficacy and mild to moderate adverse events.

Group 2. Medications with lower efficacy (i.e., limited number of studies, studies reporting conflicting results, efficacy suggesting only "modest" improvement) and mild to moderate adverse events. Group 3. Medication use based on opinion, not randomized controlled trials.

a) Low to moderate adverse events

b) Frequent or severe adverse events (or safety concerns) or complex management issues

Group 4. Medication with proven effieacy but frequent or severe adverse events (or safety concerns), or complex management issues.

Group 5. Medications proven to have limited or no efficacy.

Conclusion. The evidence-based analysis on the role of neuroimaging in migraine and the efficacy and safety of migraine therapies is one of the first and most extensive cooperative projects available for creating practice parameters across disciplines. These four evidence-based reviews reflect the high level of concern physicians have for the migraine patient, and the need for improving care across disciplines. These guidelines are intended to improve care and outcomes for all migraine sufferers. Hopefully, these evidence-based treatment guidelines for the migraine patient will be widely disseminated and provide a basis for future outcomes research.

Disclaimer. This statement is provided as an educational service of the American Academy of Neurology. It is based on an assessment of current scientific and clinical information. It is not intended to include all possible proper methods of care for a particular neurologic problem or all legitimate criteria for choosing to use a specific procedure. Neither is it intended to exclude any reasonable alternative methodologies. The AAN recognizes that specific patient care decisions are the prerogative of the patient and the physician caring for the patient, based on all of the circumstances involved.

\section{Acknowledgment}

The authors and US Headache Consortium thank Starr Pearlman, PhD, and Joanne Okagaki for their help in preparing this manuscript and for their administrative support. They also thank Jes Olesen, Jean Schoenen, Helene Massiou, Peer Tfelt Hansen, F. Cankat Tulunay, and Kai Jensen. 


\section{Appendix 1}

The US Headache Consortium: J. Keith Campbell, MD; Frederick G. Freitag, DO; Benjamin Frishberg, MD; Thomas T. Gilbert, MD, MPH; David B. Matchar, MD; Donald B. Penzien, PhD; Michael P. Pietrzak, MD, FACEP; Nabih M. Ramadan, MD; Jay H. Rosenberg, MD; Todd D. Rozen, MD; Stephen D. Silberstein, MD, FACP; Eric M. Wall, MD, MPH; William B. Young, MD.

American Academy of Neurology Quality Standards Subcommittee Members: Gary Franklin, MD, MPH—Co-chair; Catherine A. Zahn, MD - Co-chair; Milton Alter, MD, PhD; Stephen Ashwal, MD; John Calverley, MD; Richard Dubinsky, MD; Jacqueline French, MD; Michael Glantz, MD; Michael K. Greenberg, MD; Gary Gronseth, MD; Deborah Hirtz, MD; Robert G. Miller, MD; James Stevens, $\mathrm{MD}$; and William Weiner, MD

\section{Appendix 2 \\ Levels of evidence}

Level I. Independent, blind comparison with a "gold standard" of anatomy, physiology, diagnosis, or prognosis among a large number of consecutive patients suspected of having the target condition.

Level II. Independent, blind comparison with a "gold standard" among a small number of consecutive patients suspected of having the target condition.

Level III. Independent, blind comparison with a "gold standard" among nonconsecutive patients suspected of having the target condition.

Level IV: Included studies that did not meet criteria for at least Level III evidence.

\section{Strength of evidence (quality of evidence)}

Grade A. Multiple well-designed randomized clinical trials, directly relevant to the recommendation, yielded a consistent pattern of findings.

Grade B. Some evidence from randomized clinical trials supported the recommendation, but the scientific support was not optimal. For instance, few randomized trials existed, the trials that did exist were somewhat inconsistent, or the trials were not directly relevant to the recommendation. An example of the last point would be the case where trials were conducted using a study group that differed from the target group of the recommendation.

Grade C. The US Headache Consortium achieved consensus on the recommendation in the absence of relevant randomized controlled trials.

\section{Scientific effect measures}

0 The medication is ineffective or harmful. benefit)

+ The effect of the medication is either not statistically or not clinically significant (i.e., less than the minimal clinically significant

++ The effect of the medication is statistically significant and exceeds the minimally clinically significant benefit.

+++ The effect is statistically significant and far exceeds the minimally clinically significant benefit.

\section{Clinical impression of effect}

0 Ineffective: most people get no improvement.

+ Somewhat effective: few people get clinically significant improvement.

++ Effective: some people get clinically significant improvement.

+++ Very effective: most people get clinically sígnificant improvement.

\section{References}

1. Silberstein SD, Rosenberg J. Multispecialty consensus on diagnosis and treatment of headache. Neurology 2000; $54: 1553$.

2. McCrory DC, Matchar DB, Rosenberg JH, Silberstein SD. Evidence-based guidelines for migraine headache: overview of program description and methodology. Neurology [serial online]. Available at: http://www.neurology.org. Accessed April 25, 2000 .

3. Matchar DB, Young WB, Rosenberg JA, et al. Evidence-based guidelines for migraine headache in the primary care setting: pharmacological management of acute attacks. Available from the American Academy of Neurology [online]. Available at: http://www.aan.com. Accessed April 25, 2000.

4. Frishberg B, Rosenberg JH, Matchar DB, Pietrzak MP, Rozen TD. Evidence-based guidelines in the primary care setting: neuroimaging in patients with nonacute headache. Available from the American Academy of Neurology [online]. Available at: http://www.aan.com. Accessed April 25, 2000.

5. Campbell JK, Penzien D, Wall EM. Evidence-based guidelines for migraine headache: behavioral and physical treatments. Neurology [serial online]. Available at: http://www.neurology. org. Accessed April 25, 2000.

6. Ramadan NM, Silberstein SD, Freitag FG, Gilbert TT, Frishberg BM. Evidence-based guidelines for migraine headache in the primary care setting: pharmacological management for prevention of migraine. Neurology [serial online]. Available at: http://www.neurology.org. Accessed April 25, 2000.

7. Stewart WF, Lipton RB, Celentano DD, Reed ML. Prevalence of migraine in the United States. JAMA 1992; 267: 64-69.

8. Gray RN, McCrory DC, Eberlein K, Westman EC, Hasselblad V. Self-administered drug treatments for acute migraine headache. Technical Review 2.4. February 1999. (Prepared for the Agency for Health Care Policy and Research under contract no. 29009402025. Available from the National Technical Information Service; NTIS accession no. 127854.) 
9. Gray RN, McCrory DC, Eberlein K, Westman EC, Hasselblad V. Parenteral drug treatments for acute migraine headache. Technical Review 2.5. February 1999. (Prepared for the Agency for Health Care Policy and Research under contract no. 29009402025. Available from the National Technical Information Service; NTIS accession no. 127862.)

10. Gray RN, Goslin RE, McCrory DC, Eberlein K, Tulsky J, Hasselblad V. Drug treatments for the prevention of migraine headache. Technical Review 2.3. February 1999. (Prepared for the Agency for Health Care Policy and Research under contract no. 29009402025. Available from the National Technical Information Service; NTIS accession no. 127953.)

11. Goslin RE, Gray RN, McCrory DC, Penzien D, Rains J, Hasselblad V. Behavioral and physical treatments for migraine headache. Technical Review 2.2. February 1999. (Prepared for the Agency for Health Care Policy and Research under contract no. 29009402025. Available from the National Technical Information Service; NTIS accession no. 127946.)

12. Headache Classification Committee of the International Headache Society. Classification and diagnostic criteria for headache disorders, cranial neuralgia, and facial pain. Cephalalgia 1988; 8 (suppl 7): 1-96.

13. Ramirez-Lassepas M, Espinosa CE, Cicero JJ, et al. Predictors of intracranial pathologic findings in patients who seek emergency care because of headache. Arch Neurol 1997; 54: 1506-1509.

14. American Academy of Neurology. Practice parameter: The electroencephalogram in the evaluation of headache (summary statement). Report of the Quality Standards Subcommittee of the American Academy of Neurology. Neurology 1995; 45: 14111413.

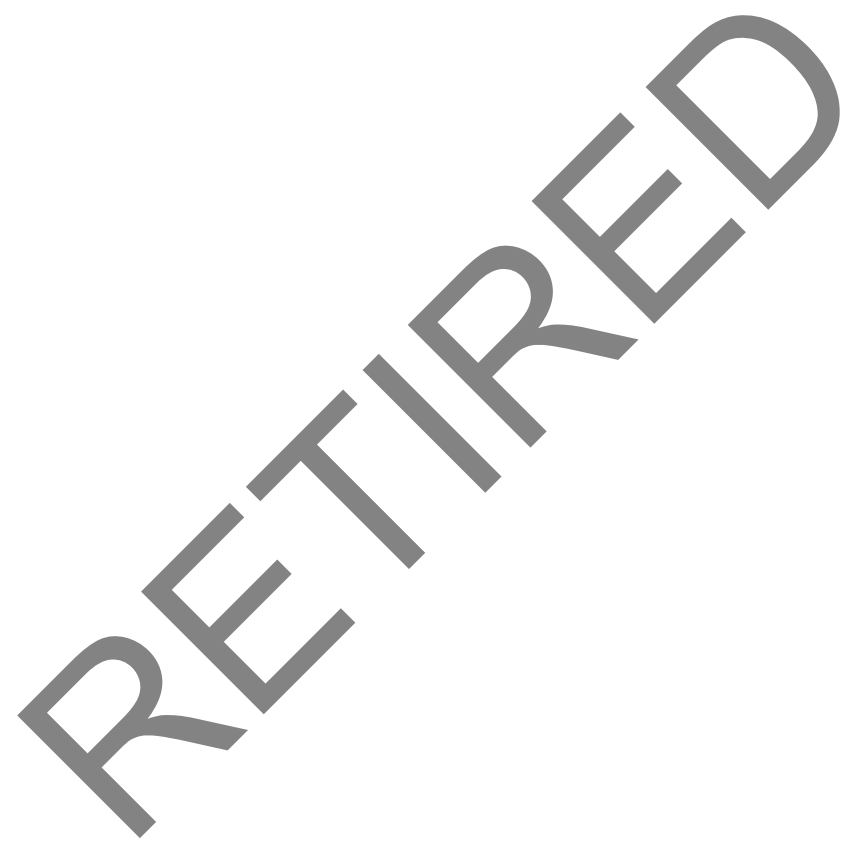




\title{
Neurology
}

\author{
Practice parameter: Evidence-based guidelines for migraine headache (an evidence-based \\ review) [RETIRED]: Report of the Quality Standards Subcommittee of the American \\ Academy of Neurology \\ Stephen D. Silberstein \\ Neurology 2000;55;754-762 \\ DOI 10.1212/WNL.55.6.754
}

This information is current as of September 26, 2000

\section{Updated Information \& \\ Services}

Citations

Permissions \& Licensing

Reprints including high resolution figures, can be found at:

http://n.neurology.org/content/55/6/754.full

This article has been cited by 45 HighWire-hosted articles: http://n.neurology.org/content/55/6/754. full\#\#otherarticles

Information about reproducing this article-in parts (figures,tables) or in its entirety can be found online at:

http://www.neurology.org/about/about_the_journal\#permissions

Information about ordering reprints can be found online:

http://n.neurology.org/subscribers/advertise

Neurology $®$ is the official journal of the American Academy of Neurology. Published continuously since 1951, it is now a weekly with 48 issues per year. Copyright . All rights reserved. Print ISSN: 0028-3878. Online ISSN: $1526-632 X$.

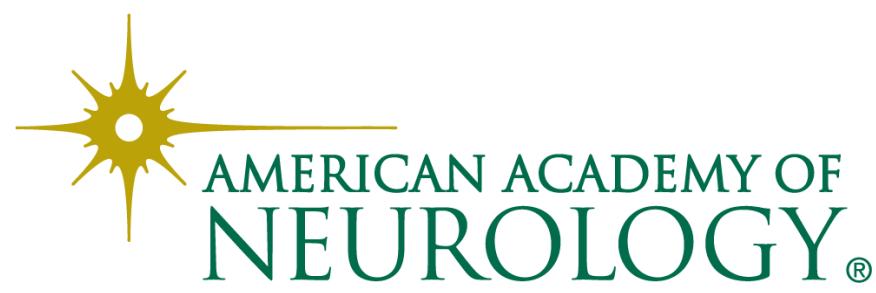




\title{
Neurology
}

\author{
Practice parameter: Evidence-based guidelines for migraine headache (an evidence-based \\ review) [RETIRED]: Report of the Quality Standards Subcommittee of the American \\ Academy of Neurology \\ Stephen D. Silberstein \\ Neurology 2000;55;754-762 \\ DOI 10.1212/WNL.55.6.754
}

This information is current as of September 26, 2000

Updated Information \&

Services

Citations

Permissions \& Licensing

Reprints including high resolution figures, can be found at: http://n.neurology.org/content/55/6/754.full

This article has been cited by 45 HighWire-hosted articles: http://n.neurology.org/content/55/6/754.full\#\#otherarticles

Information about reproducing this article in parts (figures, tables) or in its entirety can be found online at:

http://www.neurology.org/about/about_the_journal\#permissions

Information about ordering reprints can be found online:

http://n.neurology.org/subscribers/advertise

Neurology ${ }^{\circledR}$ is the official journal of the American Academy of Neurology. Published continuously since 1951, it is now a weekly with 48 issues per year. Copyright . All rights reserved. Print ISSN: 0028-3878. Online ISSN: $1526-632 \mathrm{X}$.

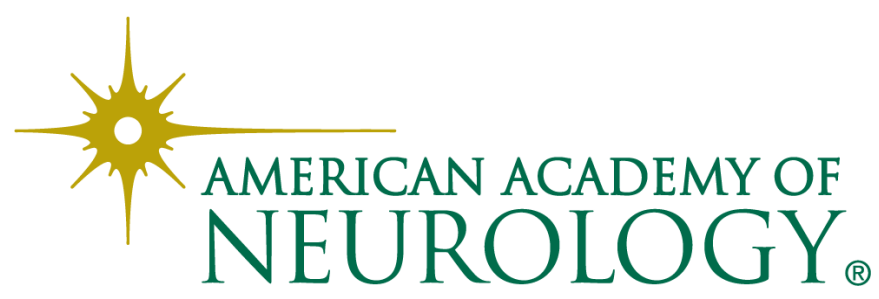

